\title{
Normalizing Plasma Renin Activity in Experimental Dilated Cardiomyopathy: Effects on Edema, Cachexia, and Survival
}

\author{
Ryan D. Sullivan ${ }^{1,2}$, Radhika M. Mehta ${ }^{1,3}$, Ranjana Tripathi ${ }^{1,3}$, Inna P. Gladysheva ${ }^{1,3, * \mathbb{C}}$ and \\ Guy L. Reed ${ }^{1,3, *}$ \\ 1 Department of Internal Medicine, University of Arizona College of Medicine-Phoenix, Phoenix, \\ AZ 85004, USA \\ 2 Department of Comparative Medicine, University of Tennessee Health Science Center, Memphis, \\ TN 38163, USA \\ 3 Department of Internal Medicine, University of Tennessee Health Science Center, Memphis, TN 38163, USA \\ * Correspondence: innagladysheva@email.arizona.edu (I.P.G.); guyreed@email.arizona.edu (G.L.R.); \\ Tel.: +1-602-827-2919 (I.P.G.); +1-602-827-2066 (G.L.R.); Fax: +1-602-827-2068 (G.L.R.)
}

Received: 1 July 2019; Accepted: 6 August 2019; Published: 9 August 2019

\begin{abstract}
Heart failure (HF) patients frequently have elevated plasma renin activity. We examined the significance of elevated plasma renin activity in a translationally-relevant model of dilated cardiomyopathy (DCM), which replicates the progressive stages (A-D) of human HF. Female mice with DCM and elevated plasma renin activity concentrations were treated with a direct renin inhibitor (aliskiren) in a randomized, blinded fashion beginning at Stage B HF. By comparison to controls, aliskiren treatment normalized pathologically elevated plasma renin activity $(p<0.001)$ and neprilysin levels $(p<0.001)$, but did not significantly alter pathological changes in plasma aldosterone, angiotensin II, atrial natriuretic peptide, or corin levels. Aliskiren improved cardiac systolic function (ejection fraction, $p<0.05$; cardiac output, $p<0.01$ ) and significantly reduced the longitudinal development of edema (extracellular water, $p<0.0001$ ), retarding the transition from Stage B to Stage $C$ HF. The normalization of elevated plasma renin activity reduced the loss of body fat and lean mass (cachexia/sarcopenia), $p<0.001)$ and prolonged survival $(p<0.05)$. In summary, the normalization of plasma renin activity retards the progression of experimental HF by improving cardiac systolic function, reducing the development of systemic edema, cachexia/sarcopenia, and mortality. These data suggest that targeting pathologically elevated plasma renin activity may be beneficial in appropriately selected HF patients.
\end{abstract}

Keywords: plasma renin activity; heart failure; aliskiren; dilated cardiomyopathy; neprilysin; edema; cachexia/sarcopenia

\section{Introduction}

Heart failure (HF) progression is affected by various pathways, including the sympathetic nervous system, the renin-angiotensin-aldosterone system (RAAS), and the natriuretic peptide (NP) system [1,2]. Activation of the RAAS is associated with left ventricular dysfunction, cardiac dilation sodium and extracellular fluid retention (edema) and cachexia/sarcopenia [3-7]. Current treatment guidelines [8,9] for HF broadly recommend therapeutics directed against angiotensin, aldosterone, or neprilysin, without the assessment of these biomarkers [5]. Nevertheless, it is increasingly recognized that there are disparities in treatment outcomes related to sex [4,7], race [10,11], geographic location [10], disease etiology, and genetic causes [12]. Analogous to cancer, HF has broad systemic effects on organs such as the lungs, kidneys, and liver, which are not emphasized by traditional classification systems [13,14]. 
Individual HF patients often have variable left ventricular (LV) function [15-19] and may progress at different clinical rates, and, thus, improving the treatment of HF may necessitate a precision medicine approach [20], which requires a two-pronged technique that relies on 1) identification of specific biomarkers, to enhance early diagnoses and etiologic classification and 2) a targeted treatment plan for the individual based on their specific profile.

Dilated cardiomyopathy (DCM) is a major cause of HF, which is associated with pathological dilation of the heart ventricles and a reduction in heart contractile or systolic function $[8,9,12,21]$. A well-established, translational mouse model of DCM with reduced ejection fraction (rEF) [22-27] fulfills the criteria of the American Heart Association Scientific Statement for Animal Models of Heart Failure [28]. We have previously reported that female mice with DCM develop HF at an accelerated rate, with worsening systolic function, increased atrial/B-type natriuretic peptides (ANP/BNP), lung edema, and reduced survival [27]. Prior to the development of Stage C HF, which is associated with edema and other biomarker abnormalities, female mice show increased plasma renin activity concentrations [27]. Renin is an enzyme that specifically catalyzes the first and rate-limiting step in the activation of angiotensin II (Ang II) and renin enhances the secretion of aldosterone, which promotes salt and water retention and worsens the development and progression of HFrEF [29-32]. Plasma renin activity increases with HF stages and varies between patient subsets [27,33]. Nevertheless, clinical studies (i.e., ASTRONAUT, ARIANA-CHF-RD, ATMOSPHERE) using direct renin inhibitors (DRI) have failed to improve outcomes in HF patients. However, these studies failed to select patients with pathological plasma renin activity levels, contained relatively few female patients, did not account for the confounding effects of other co-administered HF medications, used higher dose DRIs that affect renin as well as Ang II production, and commenced treatment late (e.g., initiation at Stage C rather than during Stage B) [34-37].

We examined the pathophysiologic contribution of elevated plasma renin activity concentrations to the progression of HFrEF as assessed by the development of edema, cachexia/sarcopenia, and mortality, in a randomized and blinded study. In contrast to previous trials, we intentionally chose an oral dose $(100 \mathrm{mg} / \mathrm{kg})$ of the DRI-aliskiren to selectively normalize pathological levels of plasma renin activity, rather than the larger doses, which may affect other pathways $[38,39]$. We show that targeted suppression with DRI-aliskiren, initiated at Stage B HF, reduces elevated plasma renin activity concentration to normal levels and decreased plasma neprilysin levels, without affecting the plasma levels of Ang II and aldosterone. The normalization of plasma renin activity was associated with improved heart systolic function, reduced edema, diminished cachexia/sarcopenia, and prolonged survival.

\section{Results}

\subsection{Normalization of Elevated Plasma Renin Activity}

The effect of renin activity normalization was assessed in female mice with DCM as they pass progressively through the stages of HF development (Figure 1a) from Stage A (no HF), to Stage B (structural heart disease), through Stage C (edema, symptoms), Stage D (severe HF), and death [40]. As we previously reported, female mice with DCM begin to show declines in heart systolic function (ejection fraction) and increases in plasma renin activity concentrations around seven weeks of age (Stage B HF) [27], which precedes the development of progressive edema, further declines in systolic function, rises in ANP/BNP, and death as is typically seen in progressive HF (Figure 1a). Based on this data, female DCM littermates were randomly assigned to aliskiren treatment (DCM+DRI) vs. no treatment (DCM+vehicle) beginning at 50 days, Stage B HF. Three groups of female littermates were blindly examined: DCM control (DCM+vehicle), DCM+DRI and wild-type (WT) mice. When evaluated at 90 days, Stage C-D HF, treatment with the DRI significantly reduced elevated plasma renin activity concentration to normal levels as expected $(p<0.01$, Figure 1b). Pathologically elevated plasma Ang II (Figure 1c) and aldosterone (Figure 1d) levels were not modulated by renin inhibition. 

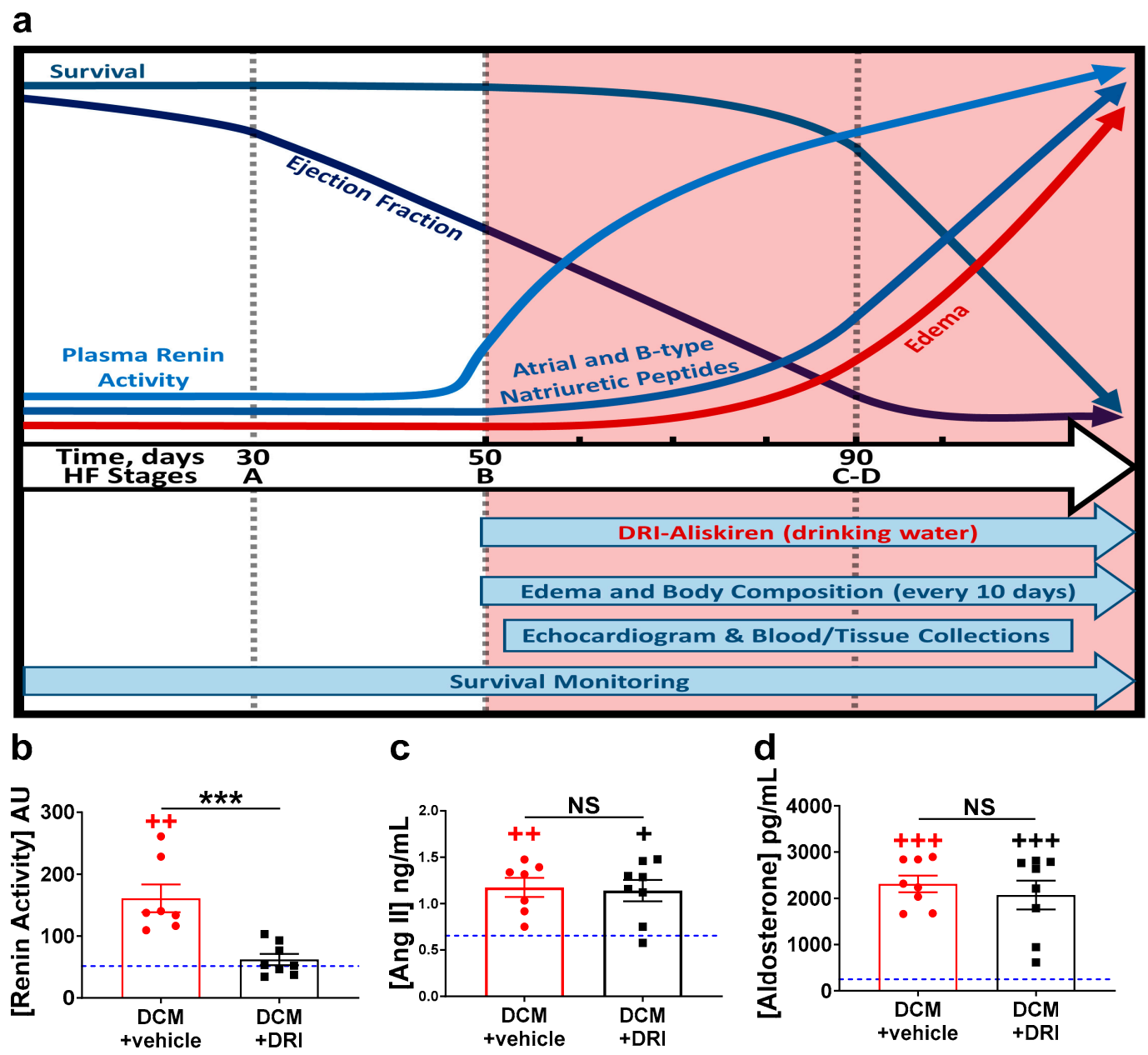

Figure 1. Heart failure stages, study design, and effects of aliskiren, a direct renin inhibitor (DRI). (a) Schematic overview of the natural history of heart failure (HF) progression, biomarker changes, and experimental design (salmon-colored area), in an established model of dilated cardiomyopathy (DCM) in female mice as reported [27]. Mice with DCM were randomly treated with aliskiren (DCM+DRI) or nothing (DCM+vehicle) in drinking water (see Methods Section). Black hash-marks indicate time points for measurement of body composition, while echocardiography and blood-tissue collection were completed at 90 days. The impact of aliskiren treatment on plasma (b) renin activity, (c) angiotensin II (Ang II), and (d) aldosterone levels at 90 days. The number of DCM mice is indicated. For reference, values for wild-type (WT) littermates are shown as a blue line $(n=4)$. Data analyzed with one-way ANOVA and represented as mean \pm SE. Not significant (NS) ${ }^{++} p<0.01,{ }^{+++} p<0.001$ (red, WT vs. DCM+vehicle; black, WT vs. DCM+DRI), ${ }^{* * *} p<0.001(\mathrm{DCM}+$ vehicle vs. DCM+DRI).

\subsection{Normalization of Plasma Renin Activity Prolongs Survival and Delays Progression of Left Ventricular Systolic Dysfunction}

WT littermates had 100\% survival throughout the 140-day study (data not presented). DCM+DRI mice significantly outlived the DCM+vehicle mice (median survival 110 vs. 103 days respectively, $p<0.05$, Figure 2a). In the same experimental groups, cardiac structure and function were assessed by echocardiography at 90 days (Stage C HF with respect to DCM+vehicle group). Systolic function in DCM mice was improved with DRI treatment as assessed with m-mode imaging (Figure $2 b$ ) and measured by ejection fraction (EF\%, $p<0.05$, Figure $2 \mathrm{c}$ ) and fractional shortening (FS\%, $p<0.05$, Figure $2 \mathrm{~d})$. Cardiac output (CO mL/min) was also improved with DRI treatment $(p<0.01$, Figure 2e), reflecting changes in both heart rate (DCM+vehicle $419 \pm 10 \mathrm{bpm}$ vs. DCM+DRI $469 \pm 14 \mathrm{bpm}, p<0.01)$ and changes in stroke volume (DCM+vehicle $11 \pm 1 \mu \mathrm{L}$ vs. DCM+DRI $16 \pm 1 \mu \mathrm{L}, p<0.05$ ). Contractile 
function assessed at 90 days by EF ( $r_{p}=0.47, p<0.001$, Figure $\left.2 \mathrm{f}\right)$ and $\mathrm{CO}\left(r_{p}=0.53, p<0.05\right.$, Figure $\left.2 \mathrm{~g}\right)$ were positively correlated with survival outcome.
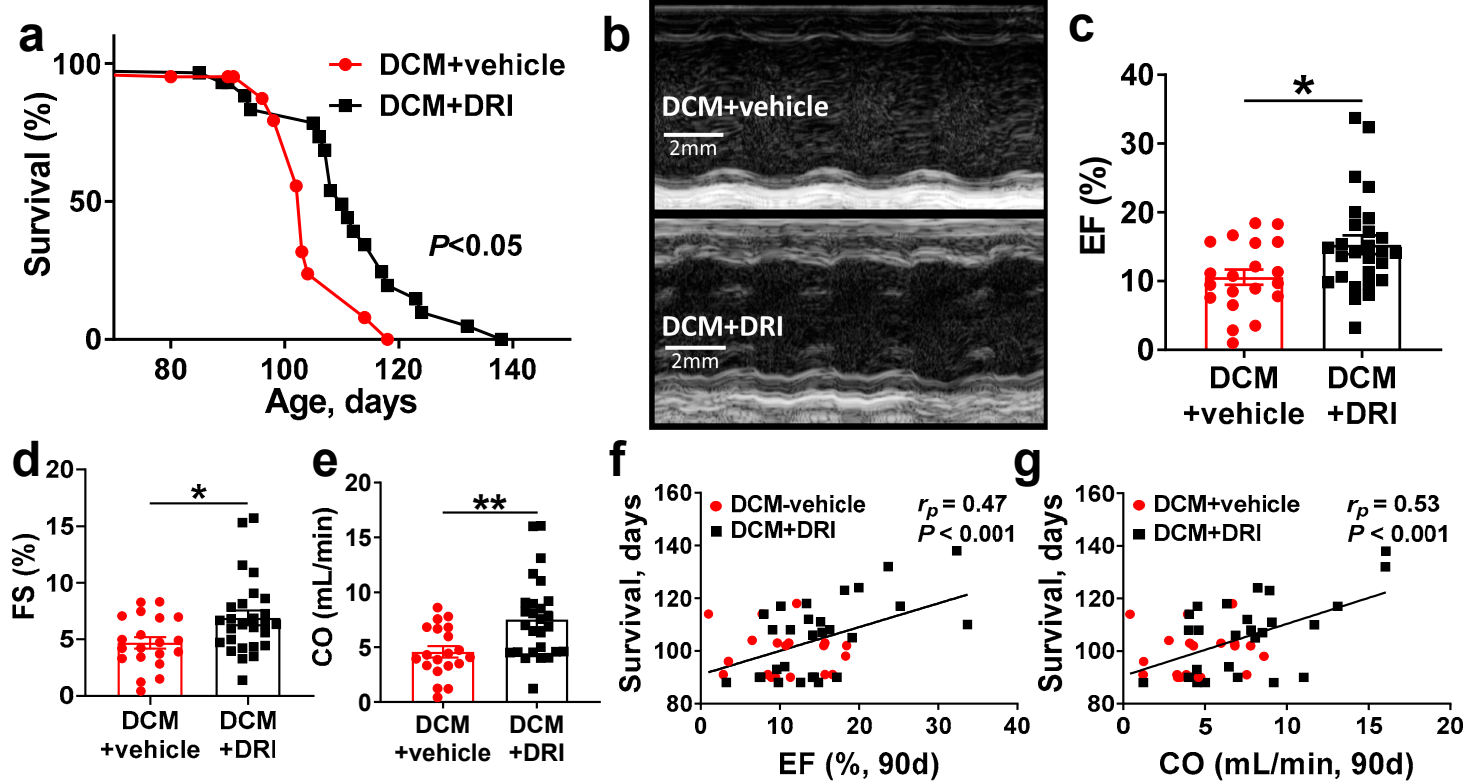

Figure 2. Direct renin inhibitor (DRI) treatment significantly improves survival and systolic function in mice with dilated cardiomyopathy (DCM). (a) Kaplan-Meier survival curves of control mice with DCM (DCM+vehicle, red, $n=13$ deaths +8 censored) vs. DCM mice treated with DRI (DCM+DRI, black, $n=21$ deaths +8 censored). WT $(n=4)$ values are provided for reference. (b) Short axis m-mode examples of DCM+vehicle and DCM+DRI treated mice at 90 days of age. (c,d) Left ventricular systolic function measured as ejection fraction $(\mathrm{EF}, \mathrm{WT}=62.8 \%$ ) and fractional shortening (FS, WT $=34 \%$ ). (e) Differences in cardiac output $(\mathrm{CO}, \mathrm{WT}=15.5 \mathrm{~mL} / \mathrm{min})$ between $\mathrm{DCM}+$ vehicle and DCM+DRI mice. (f) Pearson's correlation analysis of 90-day EF and (g) CO vs. survival. DCM control mice (DCM+vehicle, red-circle, $n=20)$, DCM mice treated with DRI (DCM+DRI, black-square, $n=27$ ). Differences between groups were analyzed by Mantel-Cox test and Mann-Whitney test. Pearson's correlation coefficient $\left(r_{p}\right)$ and $p$-values are shown. Data are represented as mean $\pm \mathrm{SE},{ }^{*} p<0.05$, ** $p<0.01$ (DCM+vehicle vs. DCM+DRI).

\subsection{Normalization of Plasma Renin Activity Delays Development of Systemic Edema and Cachexia/Sarcopenia}

To evaluate the effects of renin activity normalization, mouse hearts and lungs were examined at 90 days of age. Control (DCM+vehicle) mice had a significant increase in heart to bodyweight ratios (HW/BW) compared to WT ( $p<0.0001$, Figure 3$)$ and DCM+DRI $(p<0.05$, Figure 3$)$ mice. DRI-treated mice had an increased HW/BW ratio compared to WT ( $p<0.01$, Figure 3). DRI treatment reduced the gross increase in cardiac weight of control (DCM+vehicle) mice by $20.4 \%(p<0.05)$. Both DCM+vehicle and DCM+DRI groups were characterized by an increased lung weight to body weight (LW/BW) ratio compared to WT $(p<0.001$ and $p<0.01$ respectively, Figure 3$)$. Body weights at 90 days were not significantly different between groups (Figure 4a); as a result, the ratio differences in HW/BW and LW/BW appeared due to the increased cardiac and lung weights of the vehicle and DCM+DRI mice. 


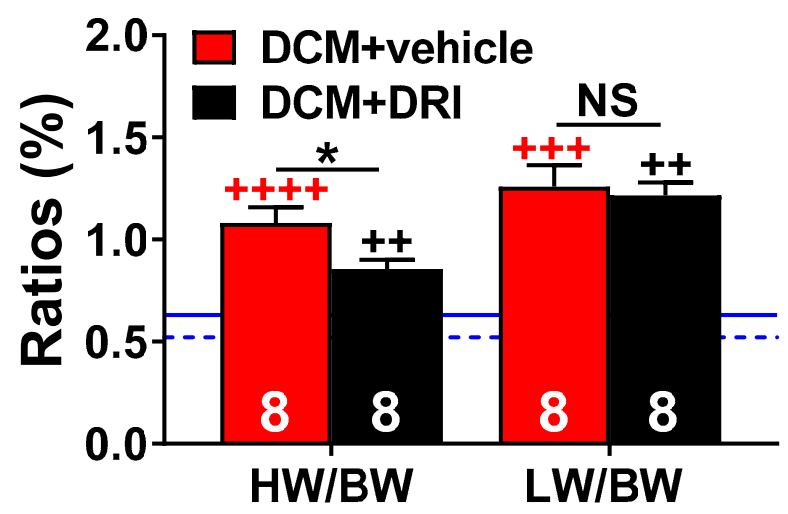

Figure 3. Morphometric changes at 90 days. Heart weight to body weight (HW/BW, \%) and lung weight to body weight (LW/BW, \%) ratios at a 90-day collection of censored subgroups. DCM control (DCM+vehicle) and aliskiren treated (DCM+DRI) group sizes are shown. For reference, the mean ratios for wild-type mice $(\mathrm{WT}, n=4)$ for $\mathrm{HW} / \mathrm{BW}$ are shown as a blue dashed line and the LW/BW as a solid blue solid line. Data were analyzed with two-tailed unpaired t-test and represented as mean \pm SE. Not significant (NS), ${ }^{++} p<0.01,{ }^{+++} p<0.001,^{++++} p<0.0001$ (red, WT vs. DCM+vehicle; black, WT vs. DCM+DRI), ${ }^{*} p<0.05$ (DCM+vehicle vs. DCM+DRI).
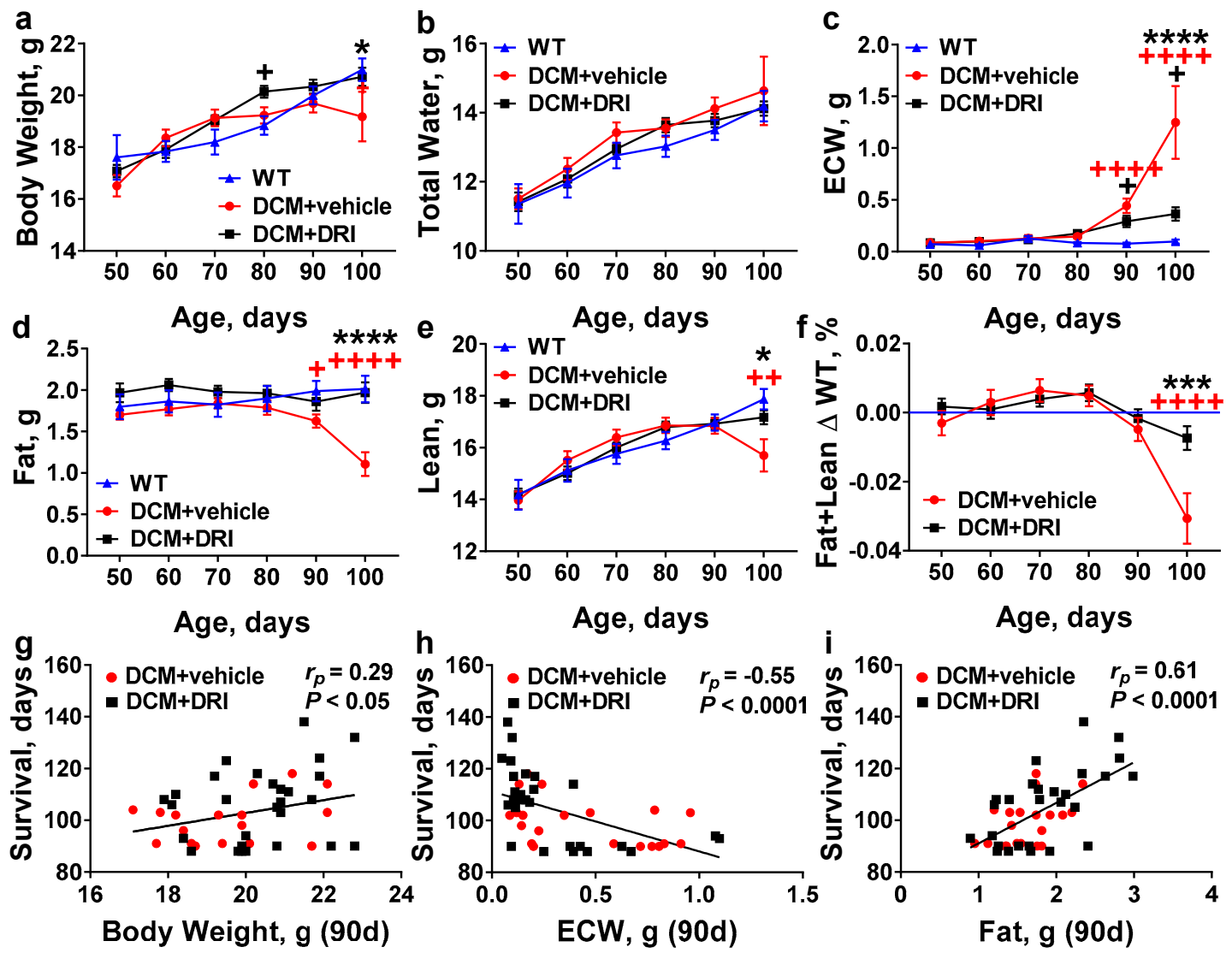

Figure 4. Effects of direct renin inhibition on systemic changes in mouse whole-body composition associated with heart failure progression. Age-related changes in (a) body weight, (b) total water, (c) extracellular water (ECW), (d) fat, (e) lean mass, and (f) combined fat and lean mass in DCM mice with (DCM+DRI) or without renin inhibition (DCM+vehicle) by comparison to wild-type (WT, without DCM) mice. WT ( $n=9-15)$, DCM+vehicle $(n=10-27)$, DCM+DRI $(n=17-29)$. (g-i) Pearson's 
correlation between survival (days) and (g) body weight; (h) extracellular water; and (i) fat measurements at 90 days. DCM+vehicle mice $(n=20)$ and DCM+DRI mice $(n=27)$. Differences between groups were analyzed by two-way ANOVA. Data are represented as the mean \pm SE. Pearson's correlation coefficient $\left(r_{p}\right)$ and $p$-values shown. ${ }^{+} p<0.05,{ }^{++} p<0.01,{ }^{+++} p<0.0001$ (red, WT vs. DCM+vehicle; black, WT vs. DCM+DRI), ${ }^{*} p<0.05,{ }^{* * *} p<0.001,{ }^{* * *} p<0.0001$ (DCM+vehicle vs. $\mathrm{DCM}+\mathrm{DRI})$.

Similar to humans with DCM, mice with DCM develop heart dilation, which progresses to symptomatic HF, water retention, and edema $[24,26,27]$. Edema is characterized not only by water retention in lung tissue (pulmonary and pleural), but also by systemic water accumulation in the cavities and/or tissues of the body (ascites and peripheral tissues). To quantify systemic water retention, we dynamically monitored body composition in all experimental groups every 10 days starting from 50 days of age, using quantitative magnetic resonance (QMR). Bodyweights were relatively consistent until 100 days when weights appeared to decline in DCM+vehicle controls compared to WT and DCM+DRI mice ( $p<0.05$ and $p<0.05$, Figure $4 a)$. Feed was provided to all mice ad-lib throughout the study; however, diet consumption was not specifically monitored. Total water measurements were similar among all groups throughout the study (Figure $4 \mathrm{~b}$ ). Systemic extracellular water (ECW, reported as free water in QMR measurements) began to rise after 80 days and became significantly elevated at 90 days of age in DCM+vehicle mice $(p<0.0001$, Figure $4 c)$. The progressive increase of ECW continued at 100 days in control (DCM+vehicle) mice compared to WT $(p<0.0001)$. Systemic ECW levels were significantly higher in DCM+vehicle vs. DCM+DRI mice when recorded at 100 days of age $(p<0.0001$, Figure 4 c).

The diagnosis of cardiac cachexia/sarcopenia in HF patients correlates strongly with an overall poor prognosis [41]. Similarly, the DCM mice developed measurable wasting as they progressed from late Stage C to terminal Stage D HF (Figure $4 \mathrm{~d}-\mathrm{f}$ ). Body fat changed in the opposite pattern; treatment with DRI resulted in the maintenance of fat levels similar to WT through 100 days, whereas $\mathrm{DCM}+$ vehicle mice showed major fat losses by 100 days $(p<0.0001$, Figure $4 \mathrm{~d})$. There was a significant decline in lean body mass in DCM control mice at 100 days, consistent with sarcopenia, by comparison to DCM+DRI and WT mice (Figure 4e). Overall there was significant wasting (Figure 4f) or cachexia, as measured by combined losses of fat and lean mass in DCM control mice by 100 days relative to WT $(p<0.0001)$ and DCM+DRI mice $(p<0.001)$.

Bodyweight at 90 days of age was marginally associated with survival (Figure $4 \mathrm{~g}$ ). A better measure was systemic ECW, which was negatively correlated with survival outcomes $\left(r_{p}=-0.55\right.$, $p<0.0001$, Figure $4 \mathrm{~h})$. Fat measurements had the best correlation $\left(r_{p}=0.61, p<0.0001\right.$, Figure 4i) with survival. Lean changes $\left(r_{p}=0.17, p=0.2591\right)$ were not significantly correlated with survival.

\subsection{Heart Failure Plasma Biomarkers Independently Respond to Direct Renin Inhibition.}

HF biomarkers were measured in subgroups of mice at 90 days (Stage C/D HF). As expected, plasma ANP ( $p<0.01$, Figure 5a) and cyclic guanosine monophosphate (cGMP, $p<0.01$, Figure 5b) levels were elevated, while plasma corin levels were reduced $(p<0.01$, Figure $5 c)$ in the DCM+vehicle group vs. WT littermates. ANP and corin plasma levels were not affected by DRI treatment (Figure $5 \mathrm{a}, \mathrm{c}$ ). Plasma cGMP levels in DCM+DRI group showed a non-significant trend toward WT levels (Figure 5b). Neprilysin levels were increased in DCM+vehicle mice compared to WT ( $p<0.05$, Figure $5 \mathrm{~d})$, consistent with human HF. DRI-aliskiren treatment, in DCM+DRI mice, normalized neprilysin to WT levels. 

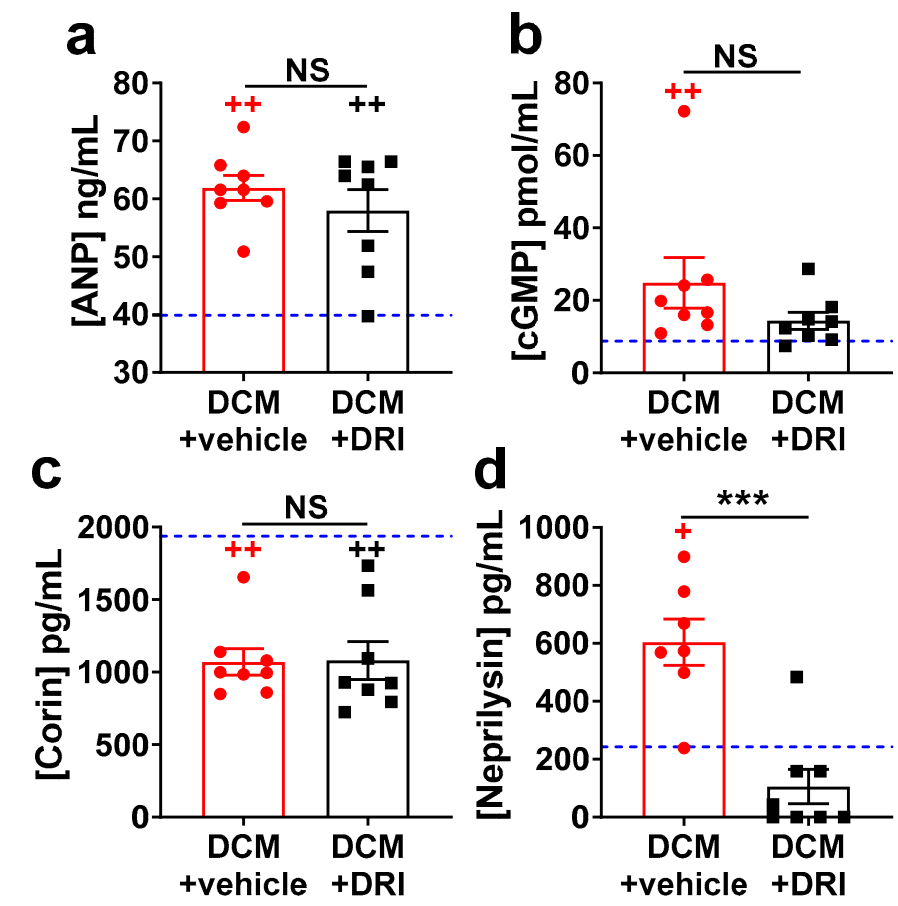

\begin{abstract}
Figure 5. Impact of direct renin inhibitor, aliskiren (DRI-aliskiren) treatment on heart failure plasma biomarkers in female mice with dilated cardiomyopathy. (a) Atrial natriuretic peptide (ANP); (b) cyclic guanosine monophosphate (cGMP); (c) corin; and (d) neprilysin plasma levels. DCM+vehicle (red bar) and DRI-aliskiren treated (DCM+DRI, black bar) group numbers are indicated. For reference, values for wild-type (WT) mice are shown as a blue dashed line $(n=4)$. Data analyzed with one-way ANOVA and represented as mean \pm SE. Not significant (NS), ${ }^{+} p<0.05,{ }^{++} p<0.01$ (red, WT vs. DCM+vehicle; black, WT vs. DCM+DRI) and ${ }^{* * *} p<0.001$ (DCM+vehicle vs. DCM+DRI).
\end{abstract}

\title{
3. Discussion
}

HF has different etiologies and patients show differences in biomarker profiles. For example, expression and activation of the enzymes, hormones, and receptors of the RAAS are modulated by a variety of factors including sex $[7,42]$. Recent experimental studies have linked elevated plasma renin activity levels in female mice with DCM to accelerated, sex-related deterioration in systolic function, HF progression, and early mortality [27]. While active renin is acknowledged to initiate production of both Ang II and aldosterone [38,43], clinical studies have not rigorously examined plasma renin activity in the pathogenesis of HF $[32,34-37,44]$. Active renin concentration was recently suggested as a potential indicator for guiding HF with reduced EF (HFrEF) in addition to BNP and New York Heart Association classification [45]. The present data, in a translationally-relevant model of $\operatorname{HFrEF}[22,23,26,27]$, is the first evidence that targeted normalization of elevated plasma renin activity concentration by direct renin inhibition, at a dose that does not alter the Ang II-aldosterone axis, significantly prolongs life, preserves left ventricular function, reduces edema formation, and delays cachexia/sarcopenia.

There are limited experimental studies exploring the direct effect of renin activity inhibition in dilated cardiomyopathy [32]. In mouse models of acute myocardial infarction with ischemic cardiomyopathy [46] and diabetic cardiomyopathy [47], DRI treatment improved systolic dysfunction and prevented remodeling. Most rodent experiments dose aliskiren via osmotic pumps for subcutaneous administration at normotensive dosages $(10-50 \mathrm{mg} / \mathrm{kg}$ SC $\approx 50-100 \%$ bioavailable $=5-25 \mathrm{mg} / \mathrm{kg})[46,48-50]$. In contrast, we elected to dose aliskiren orally $(100 \mathrm{mg} / \mathrm{kg} \approx 2.6 \%$ bioavailable $=2.6 \mathrm{mg} / \mathrm{kg}$ bioavailable) to mimic clinical administration and to take advantage of the known pharmacokinetics and pharmacodynamics of the drug as originally developed. This dose, as previously reported in mice [51], was effective in normalizing plasma renin activity (Figure 1b), but had no 
effect on Ang II levels between treated and untreated DCM groups. Although aliskiren plasma levels were not measured directly, the suppression of renin activity levels in plasma samples of DCM+DRI group compared to DCM+vehicle group supports aliskiren presence in circulation at 90 days of age, when plasma biomarkers were analyzed.

These experiments were performed in a well-characterized preclinical mouse model of DCM that is uniquely suited for the experimental re-evaluation of the role of plasma renin activity in the progression of HFrEF [22-27]. Mice with DCM pass through all stages of HFrEF with well-defined biomarker profiles, preservation of kidney function, and normal blood pressure through Stage D and death [26,27]. This animal model allowed for the investigation of DRI-aliskiren in DCM without clinical confounders (e.g., nutritional, environmental, concurrent or underlying disease status, and coadministration of additional medications). Female DCM mice were randomized to begin treatment at 50 days when pathologically elevated plasma renin activity concentration is first detected and there is an initial decline in EF corresponding to Stage B HF (Figure 1a) without the onset of edema and elevation of ANP/BNP plasma biomarkers [27,32]. DCM+DRI mice showed delayed development of Stage C HF as evidenced by the reduced ECW accumulation (edema) and a $7 \%$ increase in overall survival, which is potentially equivalent to an additional 5.6 human years assuming an 80-year lifespan. The enhanced survival was associated with (1) improvement in LV CO, (2) a robust reduction in systemic edema, and (3) prolonged maintenance of normal overall body composition (bodyweight, fat, and lean mass). When compared to DCM+vehicle treated animals, the DCM+DRI animals showed a significant absolute increase in EF of $5 \%$ and a relative increase of $33 \%$. Clinical studies have shown that in patients with low EF there is a direct correlation of EF with mortality, with higher EF being linked to better survival [52]. One of the factors most correlated with mortality was ECW retention, which is linked to the onset of edema. It is interesting to note that ECW levels greater than one gram in both groups were associated with mortality, suggesting that these levels are not compatible with survival. Clinical studies investigating edema as a biomarker for mortality $[53,54]$ support these findings; however, routine monitoring of $\mathrm{HF}$ patients currently does not include the non-invasive quantification of ECW, which precedes the onset of clinically detectable and symptomatic edema [55].

To our knowledge, this is the first study to evaluate the use of QMR as a modality to measure systemic edema (i.e., ECW) in a HF model. This technology provides a quick and non-invasive method to objectively quantify by weight, not image, body composition changes throughout the disease progression of HF; it identified changes in fat and lean mass associated with cardiac cachexia and sarcopenia in late stages of HF. Clinically, sarcopenia or muscle loss has been evaluated through dual-energy X-ray absorptiometry (DXA or DEXA, commonly referred to as bone mineral density scanning), magnetic resonance imaging (MRI), and computed tomography [56]. ECW is measured by MRI, bioelectrical impedance analysis, or bioimpedance spectroscopy [57]. The advantages of QMR were operational ease, recording speed, reproducibility, and accurate measurements that do not require interpretation of images [58-61]; this may prove to be a useful modality for monitoring human disease progression and the efficacy of therapy for HF.

Through vasodilation, natriuresis and other mechanisms, the NP system opposes the effects of active renin in HF. Suppression of pathological plasma renin activity concentration normalized plasma neprilysin and induced a trend towards normalization of cGMP levels, but did not affect plasma ANP and corin levels. This is notable, as elevated plasma neprilysin and cGMP levels reflect symptomatic $\mathrm{HF}$, while low corin levels may reflect systolic dysfunction, independent of HF clinical symptoms (i.e., edema) in human and mice with DCM [26,27,62-65]. Elevated plasma neprilysin levels are associated with enhanced mortality in clinical HF, thus the fact that normalization of pathological plasma renin activity level reduced neprilysin levels is consistent with its effects on prolonging survival [66].

Although DRI-aliskiren at $100 \mathrm{mg} / \mathrm{kg}$ normalized pathological renin activity, there was no significant difference in plasma Ang II and aldosterone levels between DCM+vehicle and DCM+DRI groups. However, it cannot be excluded that aliskiren may suppress cardiac Ang II production as reported in diabetic rats [67]. This lower dose DRI treatment normalized plasma neprilysin levels. 
Lower neprilysin levels are associated with reduced degradation of NP and of angiotensin (1-7), which promotes vasodilation and sodium excretion [68]. Although active neprilysin cleaves NP, we found that there was no correlation between levels of immunoreactive NP and immunoreactive neprilysin, which has also been noted in previous studies of HF patients [69]. Additionally, aliskiren may provide cardiac protection through induction of increased cardiac bradykinin levels $[50,70]$. Studies also suggest that renin may modulate HF through direct stimulation of (pro)-renin signaling receptor independently from angiotensinogen-angiotensin axis [71]. However, the effects of aliskiren on local cardiac, pulmonary, and renal tissues were outside the scope of the current study. Since the present studies were designed to examine the direct pathophysiologic effects of elevated plasma renin activity in HFrEF progression, they do not provide insights into how DRI monotherapy compares to other HF therapies with or without co-administration of DRI. Further studies will be necessary to determine the generalizability of these findings to other HF conditions associated with elevated renin activity and to further explore the mechanisms through which the normalization of plasma renin activity modulates fluid-retention/edema and cachexia/sarcopenia.

In HF, cardiac cachexia is associated with increased rates of morbidity and mortality, independent of ventricular function and clinical symptoms [72]. Most experts agree that bodyweight loss of $>5-6 \%$ should be used to characterize cardiac cachexia $[41,56]$. Serial QMR measurements permitted the detection of body fat and muscle losses, which may have been masked by simply following bodyweights as currently recommended for management of HF patients [9]. Changes in body composition started at 90 days of age and became significant at 100 days with declines in bodyweight $(-8.6 \%$ compared to WT), fat composition $(-45 \%)$, and lean mass $(-12 \%)$ evident in the DCM+vehicle control group. Whether these changes in body composition are due to changes in metabolism or appetite is unknown, as caloric intake was not measured. The role of RAAS modulation in the alteration of sarcopenia is recognized $[6,73,74]$. The normalization of plasma renin activity attenuated cachexia and sarcopenia, independently of alteration of plasma Ang II levels, suggests that renin activity contributes directly or indirectly to this process.

Although there are important differences between patients, nearly everyone with HFrEF is currently treated with the same medications. These studies show that normalizing the increased plasma renin activity concentration in experimental HFrEF significantly improved systolic function, delayed the onset of edema, diminished the development of cachexia/sarcopenia, and significantly extended survival. These data support the notion that increased plasma renin activity has deleterious effects in HF and suggests that, in appropriately identified individuals, the normalization of plasma renin activity may have protective effects by delaying the transition from early, asymptomatic to more severe and fatal HF.

\section{Materials and Methods}

\subsection{Institution and Environment}

All experimental activities were reviewed and approved by the Institutional Animal Care and Use Committees at the University of Tennessee Health Science Center (15-050; approved 9 July 2015 and 17-059; approved 26 July 2017) and the University of Arizona College of Medicine - Phoenix (17-303; approved 11 December 2017). All animal activities were conducted within AAALACi accredited facilities in accordance with the National Institutes of Health (NIH) Guide for the Care and Use of Laboratory Animals. Mice were housed under a 12:12 light-dark cycle; fed an ad-lib maintenance diet (Envigo Teklad 7912; Madison, WI, USA) without consumption monitoring; in individually ventilated caging system (Optimouse, Animal Care Systems; Centennial, CO, USA) with corn cob bedding (Shepherd's Cob+Plus, Shepherd Specialty Papers; Watertown, TN, USA). 


\subsection{Mice}

The mice used for this study were randomly assigned female littermates with or without dilated cardiomyopathy (DCM) on a C57BL/6 background. DCM mice express a transgene dominant-negative CREB transcription factor specific to cardiomyocytes and consistently develop the progressive stages (A-D) of HF similar to those described for humans [22-27,75]. In female mice with DCM renal function remains within a normal range up to the terminal HF stage, as measured by plasma BUN and creatinine [27]. DCM+vehicle $(n=28)$ and DCM+DRI $(n=29)$ were compared to each other. A group of congenic WT mice $(n=20)$ was used for reference. In sub-groups of 90-day old mice ( $n=8 /$ group), terminal blood was collected via cardiocentesis with ethylenediaminetetraacetic acid (EDTA)-aprotinin syringes to prevent proteolysis of targeted proteins and dissected organs were weighed. The blood samples were centrifuged at $3000 \mathrm{rpm}$ for $20 \mathrm{~min}$ at $4{ }^{\circ} \mathrm{C}$. Plasma samples were aliquoted and stored at $-80^{\circ} \mathrm{C}$ until analysis. All analysis and health/death reports were recorded by investigators and animal facility technicians who were blinded to the mouse genotype.

\subsection{Direct Renin-Inhibitor Treatment}

The direct renin-inhibitor group (DCM+DRI) was administered aliskiren hemifumarate (BOC Sciences, Shirley, NY, USA) at $100 \mathrm{mg} / \mathrm{kg} /$ day orally via single source drinking-water in autoclaved hanging bottles. Dose calculations were based on an average consumption of $5 \mathrm{~mL}$ of water/day/mouse. The bioavailability of aliskiren is low in humans and only $2.6 \%$ orally in rats [43]. Previous studies administering $15-50 \mathrm{mg} / \mathrm{kg} /$ day via subcutaneous osmotic pumps showed no alteration in blood pressure $[40,46,49,76]$. Our oral dose was chosen to closely mimic the human route of delivery, while not altering the blood pressure, associated with elevated plasma Ang II-aldosterone levels, given the low bioavailability of the drug in rodents. To prepare the solution, aliskiren powder was dissolved by shaking in volume measured autoclaved $3 \mathrm{ppm}$ hyperchlorinated facility water, mixed fresh every $72 \mathrm{~h}$ and shaken daily to resuspend. No issues with palatability or clinical dehydration were noted throughout the study as assessed by blinded husbandry and veterinary staff. There were no side effects or abnormal clinical observations in our mice throughout the treatment period. The aliskiren in drinking water was well tolerated and consumed at expected levels for plain water. The administration was started at 50 days of age to coincide with the previously identified timeline of increased renin activity and development of stage B HF in female DCM mice [27]. Aliskiren water was provided ad lib throughout life. All untreated mice (WT and DCM+vehicle) received ad lib 3 ppm hyperchlorinated facility water via an automated watering system (Edstrom, Waterford, WI, USA).

\subsection{Body Composition}

Body composition was objectively quantified by a single-blinded and experienced operator [77]. Bodyweight, free water (systemic extracellular water, ECW), total water, body fat, and lean mass were recorded longitudinally. Mice were measured every tenth day between 50-100 days using quantitative magnetic resonance (QMR) technology with an EchoMRI ${ }^{\mathrm{TM}}$ 4-in-1 Analyzer (Echo Medical Systems, Houston, TX, USA). The machine was calibrated daily per standard operating procedure using the provided canola oil (54.3 g) phantom. Briefly, mice were weighed (Scout Pro SP401, Ohaus Corporation, Pine Brook, NJ, USA) and loaded into a tube restrainer specific to the system. Mice were fully conscious and minimally restrained throughout each 60-90 s recording and were returned to their home enclosure following measurement.

\subsection{Echocardiography}

The standard transthoracic exam was performed using a Vevo 2100 Imaging System (VisualSonics; Toronto, ON, Canada) with a $30 \mathrm{MHz}$ transducer (MS 400) as previously reported [24-27]. All imaging was performed at 90 days of age (mice were treated for 35 days before subjecting to echocardiogram). Briefly, mice were induced with $3-5 \%$ isoflurane in oxygen and fur removed with depilatory cream 
(Nair, Church \& Dwight Co. Inc., Princeton, NJ, USA). Maintenance anesthesia was held at 2\% isoflurane in oxygen throughout the two-dimensional and M-mode recordings of the left ventricle (LV) in parasternal long-axis, short-axis, and four-chamber views. Mouse physiology was maintained at an anesthetized heart rate of $450 \pm 50$ beats per minute and $37 \pm 1{ }^{\circ} \mathrm{C}$ rectal temperature. The analysis was blindly completed post-recording using Vevo LAB software (3.1.0, VisualSonics) with three cardiac cycles traced to produce mean values. Ejection fraction (EF, \%), fractional shortening (FS, \%), LV mass corrected (LVMc, $\mathrm{mg}$ ), and cardiac output $(\mathrm{CO}, \mathrm{mL} / \mathrm{min}$ ) were calculated using standard equations within the software.

\subsection{Enzyme Immunoassay}

Plasma Ang II, aldosterone, atrial natriuretic peptide ( $\mathrm{N}$ terminus-ANP), cyclic guanosine monophosphate (cGMP), neprilysin, and corin levels were measured by enzyme immunoassays according to the manufacturers' protocols (Phoenix Pharm. Inc., Burlingame, CA, USA; Abcam Inc., Cambridge, MA, USA; Enzo Life Sciences Inc., Farmingdale, NY, USA; Boster Biological Technology, Pleasanton, CA, USA; USCN Life Science Inc., Houston, TX, USA) as previously reported [24-27].

\subsection{Plasma Renin Activity Assay}

Renin enzymatic activity from EDTA-aprotinin supplemented mouse plasma samples (described in the Section 4.2) were measured in a 96-well microplate (Synergy HT reader and Gen5 v1.09 software, BioTek Instruments, Inc., Winooski, VT, USA) and quantified using exogenous fluorescence

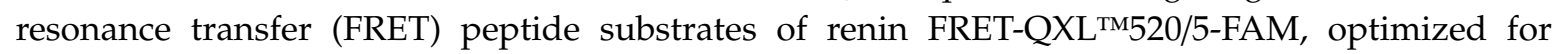
mouse renin (SensoLyte 520 mouse renin assay kit, AnaSpec, Fremont, CA, USA) as previously reported $[25,27,32,78-81]$. Cleavage of the FRET substrate by mouse renin results in the recovery of quenched fluorescence of 5-FAM, which was detected at excitation/emission $=490 / 520 \mathrm{~nm}$ with minimum autofluorescence of plasma samples. The 5-FAM fluorescent reference standard curve was used for results quantification. It is important to note that the plasma renin activity concentration assay differs from plasma renin activity (PRA) and active renin concentration (ARC)/ active plasma renin concentration (APRC) which have been historically used to report active renin in clinical trials [32].

\subsection{Statistical Analysis}

Statistical analyses were performed with GraphPad Prism 7.04 software (GraphPad Software, La Jolla, CA, USA) using Student's t-test, one-way ANOVA, or two-way ANOVA with Tukey's multiple comparisons test (unless otherwise indicated) and Pearson's correlation. Survival was analyzed using Kaplan-Meier curves with the Mantel-Cox test. Differences were considered significant if $p \leq 0.05$. The number of animals $(n)$ is indicated in the figures or figure legends. Data are represented as mean \pm SE.

\section{Conclusions}

In a translational model of DCM with $\mathrm{rEF}$, the normalization of elevated plasma renin activity concentration retards the progression of experimental HF by reducing the development of systemic edema, cachexia/sarcopenia, and mortality. Normalization of elevated plasma renin activity selectively reduces neprilysin levels without affecting levels of angiotensin II and aldosterone. Further studies are warranted to determine whether the normalization of elevated plasma renin activity may be beneficial in appropriately targeted HFrEF patients.

Author Contributions: I.P.G. and G.L.R. conceived, designed, and financially supported the study. I.P.G., G.L.R., and R.D.S. designed experiments, interpreted data, and compiled figures. I.P.G., R.D.S., R.M.M, and R.T. performed experiments and analyzed data. R.D.S., I.P.G., and G.L.R. wrote and edited the manuscript. R.M.M. and R.T. reviewed and edited the manuscript.

Funding: This study was supported by the National Institutes of Health grants NS089707 (to G.L.R.) and HL115036 (to I.P.G). 
Acknowledgments: We gratefully acknowledge the use of the QMR system and technical expertise from Ramesh Narayanan and Suriyan Ponnusamy. Many thanks to the husbandry, cagewash, supervisory, and veterinary staff of the UTHSC Cancer Research Building Laboratory Animal Care Unit for their animal care, attention to detail, and support throughout the study.

Conflicts of Interest: UA Tech Launch Arizona, along with the authors have filed patents related to this research. The authors declare no conflict of interest.

$\begin{array}{ll}\text { Abbreviations } \\ \text { HF } & \text { heart failure } \\ \text { rEF } & \text { reduced ejection fraction } \\ \text { DCM } & \text { renin-angiotensin-aldosterone-system } \\ \text { RAAS } & \text { linear dichroism } \\ \text { NP } & \text { natriuretic peptide } \\ \text { ANP } & \text { atrial natriuretic peptide } \\ \text { BNP } & \text { b-type natriuretic peptide } \\ \text { Ang II } & \text { angiotensin II } \\ \text { Ang (1-7) } & \text { angiotensin (1-7) } \\ \text { DRI } & \text { direct renin inhibitor } \\ \text { NEP } & \text { neprilysin } \\ \text { cGMP } & \text { cyclic guanosine monophosphate } \\ \text { ARC } & \text { active renin concentration } \\ \text { ELISA } & \text { enzyme-linked immunosorbent assay } \\ \text { AU } & \text { arbitrary units } \\ \text { SEM } & \text { standard error of the mean } \\ \text { WT } & \text { wild type } \\ \text { HW/BW } & \text { heart weight to bodyweight ratio } \\ \text { LW/BW } & \text { lung weight to bodyweight ratio } \\ \text { QMR } & \text { quantitative magnetic resonance } \\ \text { ECW } & \text { extracellular water } \\ \text { LV } & \text { left ventricle } \\ \text { LVMc } & \text { left ventricular mass corrected } \\ \text { PRA } & \text { plasma renin activity } \\ \text { ARC } & \text { active renin concentration } \\ \text { APRC } & \text { active plasma renin concentration } \\ & \end{array}$

\section{References}

1. Schrier, R.W.; Abraham, W.T. Hormones and hemodynamics in heart failure. N. Engl. J. Med. 1999, 341, 577-585. [CrossRef] [PubMed]

2. Volpe, M.; Carnovali, M.; Mastromarino, V. The natriuretic peptides system in the pathophysiology of heart failure: From molecular basis to treatment. Clin. Sci. (Lond.) 2016, 130, 57-77. [CrossRef] [PubMed]

3. Cohn, R.D.; van Erp, C.; Habashi, J.P.; Soleimani, A.A.; Klein, E.C.; Lisi, M.T.; Gamradt, M.; ap Rhys, C.M.; Holm, T.M.; Loeys, B.L.; et al. Angiotensin II type 1 receptor blockade attenuates TGF-beta-induced failure of muscle regeneration in multiple myopathic states. Nat. Med. 2007, 13, 204-210. [CrossRef] [PubMed]

4. Meyer, S.; van der Meer, P.; van Tintelen, J.P.; van den Berg, M.P. Sex differences in cardiomyopathies. Eur. J. Heart Fail. 2014, 16, 238-247. [CrossRef] [PubMed]

5. George, J.; Struthers, A.D.; Lang, C.C. Modulation of the renin-angiotensin-aldosterone system in heart failure. Curr. Atheroscler Rep. 2014, 16, 403. [CrossRef] [PubMed]

6. Sartiani, L.; Spinelli, V.; Laurino, A.; Blescia, S.; Raimondi, L.; Cerbai, E.; Mugelli, A. Pharmacological perspectives in sarcopenia: A potential role for renin-angiotensin system blockers? Clin. Cases. Min. Bone Metab. 2015, 12, 135-138. [CrossRef] [PubMed] 
7. Eisenberg, E.; Di Palo, K.E.; Pina, I.L. Sex differences in heart failure. Clin. Cardiol. 2018, 41, $211-216$. [CrossRef] [PubMed]

8. Yancy, C.W.; Jessup, M.; Bozkurt, B.; Butler, J.; Casey, D.E., Jr.; Colvin, M.M.; Drazner, M.H.; Filippatos, G.; Fonarow, G.C.; Givertz, M.M.; et al. 2016 ACC/AHA/HFSA Focused Update on New Pharmacological Therapy for Heart Failure: An Update of the 2013 ACCF/AHA Guideline for the Management of Heart Failure: A Report of the American College of Cardiology/American Heart Association Task Force on Clinical Practice Guidelines and the Heart Failure Society of America. J. Am. Coll. Cardiol. 2016, 68, 1476-1488. [CrossRef] [PubMed]

9. Yancy, C.W.; Jessup, M.; Bozkurt, B.; Butler, J.; Casey, D.E., Jr.; Drazner, M.H.; Fonarow, G.C.; Geraci, S.A.; Horwich, T.; Januzzi, J.L.; et al. 2013 ACCF/AHA guideline for the management of heart failure: Executive summary: A report of the American College of Cardiology Foundation/American Heart Association Task Force on practice guidelines. Circulation 2013, 128, 1810-1852. [CrossRef] [PubMed]

10. Akwo, E.A.; Kabagambe, E.K.; Wang, T.J.; Harrell, F.E., Jr.; Blot, W.J.; Mumma, M.; Gupta, D.K.; Lipworth, L. Heart Failure Incidence and Mortality in the Southern Community Cohort Study. Circ. Heart Fail. 2017, 10. [CrossRef] [PubMed]

11. Lewis, E.F.; Claggett, B.; Shah, A.M.; Liu, J.; Shah, S.J.; Anand, I.; O’Meara, E.; Sweitzer, N.K.; Rouleau, J.L.; Fang, J.C.; et al. Racial Differences in Characteristics and Outcomes of Patients With Heart Failure and Preserved Ejection Fraction in the Treatment of Preserved Cardiac Function Heart Failure Trial. Circ. Heart Fail. 2018, 11, e004457. [CrossRef] [PubMed]

12. McNally, E.M.; Mestroni, L. Dilated Cardiomyopathy: Genetic Determinants and Mechanisms. Circ. Res. 2017, 121, 731-748. [CrossRef] [PubMed]

13. Fedele, F.; Severino, P.; Calcagno, S.; Mancone, M. Heart failure: TNM-like classification. J. Am. Coll. Cardiol. 2014, 63, 1959-1960. [CrossRef] [PubMed]

14. Severino, P.; Mestrini, V.; Mariani, M.V.; Birtolo, L.I.; Scarpati, R.; Mancone, M.; Fedele, F. Structural and myocardial dysfunction in heart failure beyond ejection fraction. Heart Fail. Rev. 2019. [CrossRef] [PubMed]

15. Ziaeian, B.; Fonarow, G.C. Epidemiology and aetiology of heart failure. Nat. Rev. Cardiol. 2016, 13, 368-378. [CrossRef]

16. Fedele, F.; Mancone, M.; Adamo, F.; Severino, P. Heart Failure With Preserved, Mid-Range, and Reduced Ejection Fraction: The Misleading Definition of the New Guidelines. Cardiol. Rev. 2017, 25, 4-5. [CrossRef] [PubMed]

17. Orsborne, C.; Chaggar, P.S.; Shaw, S.M.; Williams, S.G. The renin-angiotensin-aldosterone system in heart failure for the non-specialist: The past, the present and the future. Postgrad. Med. J. 2017, 93, 29-37. [CrossRef]

18. Metra, M.; Teerlink, J.R. Heart failure. Lancet 2017, 390, 1981-1995. [CrossRef]

19. Seferovic, P.M.; Polovina, M.; Bauersachs, J.; Arad, M.; Gal, T.B.; Lund, L.H.; Felix, S.B.; Arbustini, E.; Caforio, A.L.P.; Farmakis, D.; et al. Heart failure in cardiomyopathies: A position paper from the Heart Failure Association of the European Society of Cardiology. Eur. J. Heart Fail. 2019, 21, 553-576. [CrossRef]

20. Antman, E.M.; Loscalzo, J. Precision medicine in cardiology. Nat. Rev. Cardiol. 2016, 13, 591-602. [CrossRef]

21. Bozkurt, B.; Colvin, M.; Cook, J.; Cooper, L.T.; Deswal, A.; Fonarow, G.C.; Francis, G.S.; Lenihan, D.; Lewis, E.F.; McNamara, D.M.; et al. Current Diagnostic and Treatment Strategies for Specific Dilated Cardiomyopathies: A Scientific Statement From the American Heart Association. Circulation 2016, 134, e579-e646. [CrossRef] [PubMed]

22. Fentzke, R.C.; Korcarz, C.E.; Lang, R.M.; Lin, H.; Leiden, J.M. Dilated cardiomyopathy in transgenic mice expressing a dominant-negative CREB transcription factor in the heart. J. Clin. Invest. 1998, 101, 2415-2426. [CrossRef] [PubMed]

23. Watson, P.A.; Birdsey, N.; Huggins, G.S.; Svensson, E.; Heppe, D.; Knaub, L. Cardiac-specific overexpression of dominant-negative CREB leads to increased mortality and mitochondrial dysfunction in female mice. Am. J. Physiol. Heart Circ. Physiol. 2010, 299, H2056-H2068. [CrossRef] [PubMed]

24. Gladysheva, I.P.; Wang, D.; McNamee, R.A.; Houng, A.K.; Mohamad, A.A.; Fan, T.M.; Reed, G.L. Corin overexpression improves cardiac function, heart failure, and survival in mice with dilated cardiomyopathy. Hypertension 2013, 61, 327-332. [CrossRef]

25. Wang, D.; Gladysheva, I.P.; Fan, T.H.; Sullivan, R.; Houng, A.K.; Reed, G.L. Atrial natriuretic peptide affects cardiac remodeling, function, heart failure, and survival in a mouse model of dilated cardiomyopathy. Hypertension 2014, 63, 514-519. [CrossRef] [PubMed] 
26. Tripathi, R.; Wang, D.; Sullivan, R.; Fan, T.H.; Gladysheva, I.P.; Reed, G.L. Depressed Corin Levels Indicate Early Systolic Dysfunction Before Increases of Atrial Natriuretic Peptide/B-Type Natriuretic Peptide and Heart Failure Development. Hypertension 2016, 67, 362-367. [CrossRef] [PubMed]

27. Tripathi, R.; Sullivan, R.; Fan, T.M.; Wang, D.; Sun, Y.; Reed, G.L.; Gladysheva, I.P. Enhanced heart failure, mortality and renin activation in female mice with experimental dilated cardiomyopathy. PLoS ONE 2017, 12, e0189315. [CrossRef] [PubMed]

28. Houser, S.R.; Margulies, K.B.; Murphy, A.M.; Spinale, F.G.; Francis, G.S.; Prabhu, S.D.; Rockman, H.A.; Kass, D.A.; Molkentin, J.D.; Sussman, M.A.; et al. Animal models of heart failure: A scientific statement from the American Heart Association. Circ. Res. 2012, 111, 131-150. [CrossRef] [PubMed]

29. Skeggs, L.T., Jr.; Kahn, J.R.; Lentz, K.; Shumway, N.P. The preparation, purification, and amino acid sequence of a polypeptide renin substrate. J. Exp. Med. 1957, 106, 439-453. [CrossRef] [PubMed]

30. Weber, K.T. Aldosterone in congestive heart failure. N. Engl. J. Med. 2001, 345, 1689-1697. [CrossRef] [PubMed]

31. Wang, Y.; Seto, S.W.; Golledge, J. Angiotensin II, sympathetic nerve activity and chronic heart failure. Heart Fail. Rev. 2014, 19, 187-198. [CrossRef] [PubMed]

32. Sullivan, R.D.; Mehta, R.M.; Tripathi, R.; Reed, G.L.; Gladysheva, I.P. Renin Activity in Heart Failure with Reduced Systolic Function-New Insights. Int. J. Mol. Sci. 2019, 20, 3182. [CrossRef] [PubMed]

33. Mentz, R.J.; Stevens, S.R.; DeVore, A.D.; Lala, A.; Vader, J.M.; AbouEzzeddine, O.F.; Khazanie, P.; Redfield, M.M.; Stevenson, L.W.; O'Connor, C.M.; et al. Decongestion strategies and renin-angiotensin-aldosterone system activation in acute heart failure. JACC Heart Fail. 2015, 3, 97-107. [CrossRef] [PubMed]

34. Seed, A.; Gardner, R.; McMurray, J.; Hillier, C.; Murdoch, D.; MacFadyen, R.; Bobillier, A.; Mann, J.; McDonagh, T. Neurohumoral effects of the new orally active renin inhibitor, aliskiren, in chronic heart failure. Eur. J. Heart Fail. 2007, 9, 1120-1127. [CrossRef] [PubMed]

35. Gheorghiade, M.; Bohm, M.; Greene, S.J.; Fonarow, G.C.; Lewis, E.F.; Zannad, F.; Solomon, S.D.; Baschiera, F.; Botha, J.; Hua, T.A.; et al. Effect of aliskiren on postdischarge mortality and heart failure readmissions among patients hospitalized for heart failure: The ASTRONAUT randomized trial. JAMA 2013, 309, 1125-1135. [CrossRef]

36. Schroten, N.F.; Damman, K.; Hemmelder, M.H.; Voors, A.A.; Navis, G.; Gaillard, C.A.; van Veldhuisen, D.J.; Van Gilst, W.H.; Hillege, H.L. Effect of additive renin inhibition with aliskiren on renal blood flow in patients with Chronic Heart Failure and Renal Dysfunction (Additive Renin Inhibition with Aliskiren on renal blood flow and Neurohormonal Activation in patients with Chronic Heart Failure and Renal Dysfunction). Am. Heart J. 2015, 169, 693-701.

37. McMurray, J.J.; Krum, H.; Abraham, W.T.; Dickstein, K.; Kober, L.V.; Desai, A.S.; Solomon, S.D.; Greenlaw, N.; Ali, M.A.; Chiang, Y.; et al. Aliskiren, Enalapril, or Aliskiren and Enalapril in Heart Failure. N Engl J. Med. 2016, 374, 1521-1532. [CrossRef]

38. Wal, P.; Wal, A.; Rai, A.K.; Dixit, A. Aliskiren: An orally active renin inhibitor. J. Pharm. Bioallied. Sci. 2011, 3, 189-193. [CrossRef]

39. Liu, H.; Luo, H.; Wang, S.; Zhang, C.; Hao, J.; Gao, C. Aliskiren for heart failure: A systematic review and meta-analysis of randomized controlled trials. Oncotarget 2017, 8, 88189-88198. [CrossRef]

40. Yamada, C.; Kuwahara, K.; Yamazaki, M.; Nakagawa, Y.; Nishikimi, T.; Kinoshita, H.; Kuwabara, Y.; Minami, T.; Yamada, Y.; Shibata, J.; et al. The renin-angiotensin system promotes arrhythmogenic substrates and lethal arrhythmias in mice with non-ischaemic cardiomyopathy. Cardiovasc. Res. 2016, 109, 162-173. [CrossRef]

41. Anker, S.D.; Sharma, R. The syndrome of cardiac cachexia. Int. J. Cardiol. 2002, 85, 51-66. [CrossRef]

42. Fischer, M.; Baessler, A.; Schunkert, H. Renin angiotensin system and gender differences in the cardiovascular system. Cardiovasc. Res. 2002, 53, 672-677. [CrossRef]

43. Muller, D.N.; Derer, W.; Dechend, R. Aliskiren-mode of action and preclinical data. J. Mol. Med. (Berl) 2008, 86, 659-662. [CrossRef] [PubMed]

44. Solomon, S.D.; Shin, S.H.; Shah, A.; Skali, H.; Desai, A.; Kober, L.; Maggioni, A.P.; Rouleau, J.L.; Kelly, R.Y.; Hester, A.; et al. Aliskiren Study in Post, M.I.P. t. R. R. I., Effect of the direct renin inhibitor aliskiren on left ventricular remodelling following myocardial infarction with systolic dysfunction. Eur. Heart J. 2011, 32, 1227-1234. [CrossRef] [PubMed] 
45. Pavo, N.; Goliasch, G.; Wurm, R.; Novak, J.; Strunk, G.; Gyongyosi, M.; Poglitsch, M.; Saemann, M.D.; Hulsmann, M. Low- and High-renin Heart Failure Phenotypes with Clinical Implications. Clin. Chem. 2018, 64, 597-608. [CrossRef] [PubMed]

46. Westermann, D.; Riad, A.; Lettau, O.; Roks, A.; Savvatis, K.; Becher, P.M.; Escher, F.; Jan Danser, A.H.; Schultheiss, H.P.; Tschope, C. Renin inhibition improves cardiac function and remodeling after myocardial infarction independent of blood pressure. Hypertension 2008, 52, 1068-1075. [CrossRef] [PubMed]

47. Thomas, C.M.; Yong, Q.C.; Seqqat, R.; Chandel, N.; Feldman, D.L.; Baker, K.M.; Kumar, R. Direct renin inhibition prevents cardiac dysfunction in a diabetic mouse model: Comparison with an angiotensin receptor antagonist and angiotensin-converting enzyme inhibitor. Clin. Sci. (Lond) 2013, 124, 529-541. [CrossRef]

48. Connelly, K.A.; Advani, A.; Advani, S.; Zhang, Y.; Thai, K.; Thomas, S.; Krum, H.; Kelly, D.J.; Gilbert, R.E. Combination angiotensin converting enzyme and direct renin inhibition in heart failure following experimental myocardial infarction. Cardiovasc. Ther. 2013, 31, 84-91. [CrossRef]

49. Yang, N.I.; Liao, C.C.; Hung, M.J.; Cherng, W.J. Direct Renin Inhibitor Attenuates Left Ventricular Remodeling in Post-Myocardial Infarction Heart Failure Mice. Acta Cardiol. Sin. 2013, 29, 160-167.

50. Koid, S.S.; Ziogas, J.; Campbell, D.J. Aliskiren reduces myocardial ischemia-reperfusion injury by a bradykinin B2 receptor- and angiotensin AT2 receptor-mediated mechanism. Hypertension 2014, 63, 768-773. [CrossRef]

51. Desjarlais, M.; Dussault, S.; Dhahri, W.; Mathieu, R.; Rivard, A. Direct renin inhibition with aliskiren improves ischemia-induced neovascularization: Blood pressure-independent effect. Atherosclerosis 2015, 242, 450-460. [CrossRef] [PubMed]

52. Toma, M.; Ezekowitz, J.A.; Bakal, J.A.; O’Connor, C.M.; Hernandez, A.F.; Sardar, M.R.; Zolty, R.; Massie, B.M.; Swedberg, K.; Armstrong, P.W.; et al. The relationship between left ventricular ejection fraction and mortality in patients with acute heart failure: Insights from the ASCEND-HF Trial. Eur. J. Heart Fail. 2014, 16, 334-341. [CrossRef] [PubMed]

53. Henriquez-Palop, F.; Anton-Perez, G.; Marrero-Robayna, S.; Gonzalez-Cabrera, F.; Rodriguez-Perez, J.C. Water overload as a biomarker for heart failure and acute renal failure. Nefrologia 2013, 33, 256-265. [CrossRef] [PubMed]

54. Kim, E.J.; Choi, M.J.; Lee, J.H.; Oh, J.E.; Seo, J.W.; Lee, Y.K.; Yoon, J.W.; Kim, H.J.; Noh, J.W.; Koo, J.R. Extracellular Fluid/Intracellular Fluid Volume Ratio as a Novel Risk Indicator for All-Cause Mortality and Cardiovascular Disease in Hemodialysis Patients. PLoS ONE 2017, 12. [CrossRef] [PubMed]

55. Pellicori, P.; Kaur, K.; Clark, A.L. Fluid Management in Patients with Chronic Heart Failure. Card. Fail. Rev. 2015, 1, 90-95. [CrossRef] [PubMed]

56. Okoshi, M.P.; Capalbo, R.V.; Romeiro, F.G.; Okoshi, K. Cardiac Cachexia: Perspectives for Prevention and Treatment. Arq. Bras. Cardiol. 2017, 108, 74-80. [CrossRef] [PubMed]

57. Jaffrin, M.Y.; Morel, H. Body fluid volumes measurements by impedance: A review of bioimpedance spectroscopy (BIS) and bioimpedance analysis (BIA) methods. Med. Eng. Phys. 2008, 30, 1257-1269. [CrossRef]

58. Kovner, I.; Taicher, G.Z.; Mitchell, A.D. Calibration and validation of EchoMRI whole body composition analysis based on chemical analysis of piglets, in comparison with the same for DXA. Int. J. Body Compos. Res. 2010, 8, 17-29.

59. Gallagher, D.; Thornton, J.C.; He, Q.; Wang, J.; Yu, W.; Bradstreet, T.E.; Burke, J.; Heymsfield, S.B.; Rivas, V.M.; Kaufman, R. Quantitative magnetic resonance fat measurements in humans correlate with established methods but are biased. Obes. (Silver Spring) 2010, 18, 2047-2054. [CrossRef]

60. Metzinger, M.N.; Miramontes, B.; Zhou, P.; Liu, Y.; Chapman, S.; Sun, L.; Sasser, T.A.; Duffield, G.E.; Stack, M.S.; Leevy, W.M. Correlation of X-ray computed tomography with quantitative nuclear magnetic resonance methods for pre-clinical measurement of adipose and lean tissues in living mice. Sensors 2014, 14, 18526-18542. [CrossRef]

61. Toro-Ramos, T.; Paley, C.; Wong, W.W.; Pi-Sunyer, F.X.; Yu, W.W.; Thornton, J.; Gallagher, D. Reliability of the EchoMRI Infants System for Water and Fat Measurements in Newborns. Obes. (Silver Spring) 2017, 25, 1577-1583. [CrossRef] [PubMed] 
62. Zaidi, S.S.; Ward, R.D.; Ramanathan, K.; Yu, X.; Gladysheva, I.P.; Reed, G.L. Possible Enzymatic Downregulation of the Natriuretic Peptide System in Patients with Reduced Systolic Function and Heart Failure: A Pilot Study. BioMed. Res. Int. 2018, 2018, 6. [CrossRef] [PubMed]

63. Ibebuogu, U.N.; Gladysheva, I.P.; Houng, A.K.; Reed, G.L. Decompensated heart failure is associated with reduced corin levels and decreased cleavage of pro-atrial natriuretic peptide. Circ. Heart Fail. 2011, 4, 114-120. [CrossRef] [PubMed]

64. Bayes-Genis, A.; Barallat, J.; Richards, A.M. A Test in Context: Neprilysin: Function, Inhibition, and Biomarker. J. Am. Coll. Cardiol. 2016, 68, 639-653. [CrossRef] [PubMed]

65. McKee, P.A.; Castelli, W.P.; McNamara, P.M.; Kannel, W.B. The natural history of congestive heart failure: The Framingham study. N. Engl. J. Med. 1971, 285, 1441-1446. [CrossRef] [PubMed]

66. Bayes-Genis, A.; Barallat, J.; Galan, A.; de Antonio, M.; Domingo, M.; Zamora, E.; Urrutia, A.; Lupon, J. Soluble neprilysin is predictive of cardiovascular death and heart failure hospitalization in heart failure patients. J. Am. Coll. Cardiol. 2015, 65, 657-665. [CrossRef]

67. Singh, V.P.; Le, B.; Khode, R.; Baker, K.M.; Kumar, R. Intracellular angiotensin II production in diabetic rats is correlated with cardiomyocyte apoptosis, oxidative stress, and cardiac fibrosis. Diabetes 2008, 57, 3297-3306. [CrossRef]

68. Von Lueder, T.G.; Sangaralingham, S.J.; Wang, B.H.; Kompa, A.R.; Atar, D.; Burnett, J.C., Jr.; Krum, H. Renin-angiotensin blockade combined with natriuretic peptide system augmentation: Novel therapeutic concepts to combat heart failure. Circ. Heart Fail. 2013, 6, 594-605. [CrossRef]

69. Vodovar, N.; Seronde, M.F.; Laribi, S.; Gayat, E.; Lassus, J.; Januzzi, J.L., Jr.; Boukef, R.; Nouira, S.; Manivet, P.; Samuel, J.L.; et al. Elevated Plasma B-Type Natriuretic Peptide Concentrations Directly Inhibit Circulating Neprilysin Activity in Heart Failure. JACC Heart Fail. 2015, 3, 629-636. [CrossRef]

70. Campbell, D.J.; Zhang, Y.; Kelly, D.J.; Gilbert, R.E.; McCarthy, D.J.; Shi, W.; Smyth, G.K. Aliskiren increases bradykinin and tissue kallikrein mRNA levels in the heart. Clin. Exp. Pharm. Physiol. 2011, 38, 623-631. [CrossRef]

71. Hirose, T.; Mori, N.; Totsune, K.; Morimoto, R.; Maejima, T.; Kawamura, T.; Metoki, H.; Asayama, K.; Kikuya, M.; Ohkubo, T.; et al. Gene expression of (pro)renin receptor is upregulated in hearts and kidneys of rats with congestive heart failure. Peptides 2009, 30, 2316-2322. [CrossRef] [PubMed]

72. Rossignol, P.; Masson, S.; Barlera, S.; Girerd, N.; Castelnovo, A.; Zannad, F.; Clemenza, F.; Tognoni, G.; Anand, I.S.; Cohn, J.N.; et al. Loss in body weight is an independent prognostic factor for mortality in chronic heart failure: Insights from the GISSI-HF and Val-HeFT trials. Eur. J. Heart Fail. 2015, 17, 424-433. [CrossRef] [PubMed]

73. Carter, C.S.; Groban, L. Role of the renin-angiotensin system in age-related sarcopenia and diastolic dysfunction. Aging Health 2008, 4, 37-46. [CrossRef] [PubMed]

74. Sukhanov, S.; Semprun-Prieto, L.; Yoshida, T.; Michael Tabony, A.; Higashi, Y.; Galvez, S.; Delafontaine, P. Angiotensin II, oxidative stress and skeletal muscle wasting. Am. J. Med. Sci. 2011, 342, 143-147. [CrossRef] [PubMed]

75. Huggins, G.S.; Lepore, J.J.; Greytak, S.; Patten, R.; McNamee, R.; Aronovitz, M.; Wang, P.J.; Reed, G.L. The CREB leucine zipper regulates CREB phosphorylation, cardiomyopathy, and lethality in a transgenic model of heart failure. Am. J. Physiol. Heart Circ. Physiol. 2007, 293, H1877-H1882. [CrossRef]

76. Poss, J.; Werner, C.; Lorenz, D.; Gensch, C.; Bohm, M.; Laufs, U. The renin inhibitor aliskiren upregulates pro-angiogenic cells and reduces atherogenesis in mice. Basic. Res. Cardiol. 2010, 105, 725-735. [CrossRef] [PubMed]

77. Ponnusamy, S.; Sullivan, R.D.; You, D.; Zafar, N.; He Yang, C.; Thiyagarajan, T.; Johnson, D.L.; Barrett, M.L.; Koehler, N.J.; Star, M.; et al. Androgen receptor agonists increase lean mass, improve cardiopulmonary functions and extend survival in preclinical models of Duchenne muscular dystrophy. Hum. Mol. Genet. 2017, 26, 2526-2540. [CrossRef]

78. Schmiedt, C.W.; Hurley, K.A.; Tong, X.; Rakhmanova, V.A.; Po, C.L.; Hurley, D.J. Measurement of plasma renin concentration in cats by use of a fluorescence resonance energy transfer peptide substrate of renin. $A m$. J. Vet. Res. 2009, 70, 1315-1322. [CrossRef]

79. Prysyazhna, O.; Rudyk, O.; Eaton, P. Single atom substitution in mouse protein kinase G eliminates oxidant sensing to cause hypertension. Nat. Med. 2012, 18, 286-290. [CrossRef] 
80. Kakoki, M.; Pochynyuk, O.M.; Hathaway, C.M.; Tomita, H.; Hagaman, J.R.; Kim, H.S.; Zaika, O.L.; Mamenko, M.; Kayashima, Y.; Matsuki, K.; et al. Primary aldosteronism and impaired natriuresis in mice underexpressing TGFbeta1. Proc. Natl. Acad. Sci. USA 2013, 110, 5600-5605. [CrossRef]

81. Takada, S.; Kinugawa, S.; Hirabayashi, K.; Suga, T.; Yokota, T.; Takahashi, M.; Fukushima, A.; Homma, T.; Ono, T.; Sobirin, M.A.; et al. Angiotensin II receptor blocker improves the lowered exercise capacity and impaired mitochondrial function of the skeletal muscle in type 2 diabetic mice. J. Appl. Physiol. 2013, 114, 844-857. [CrossRef] [PubMed]

C 2019 by the authors. Licensee MDPI, Basel, Switzerland. This article is an open access article distributed under the terms and conditions of the Creative Commons Attribution (CC BY) license (http://creativecommons.org/licenses/by/4.0/). 